\title{
Tutor, trener, mentor i coach - współczesny nauczyciel matematyki
}

$\mathrm{Na}$ jakość nauczania nie tylko matematyki mają niewątpliwie wpływ wiedza, umiejętności i postawa nauczyciela. Stworzenie portretu idealnego nauczyciela matematyki jest niemożliwe, jednak można wyodrębnić pewne cechy, którymi powinien się on charakteryzować.

\section{Jaki zatem powinien być „wystarczająco dobry nauczyciel" matematyki?}

Powinien ze spokojem realizować swoją misję i wypełniać obowiązki i nie frasować się, że nie jest mistrzem w każdej dziedzinie, co nie znaczy, że ma odpuszczać i poddawać się. Uczniowie nie potrzebują przecież ideału, chcą „wystarczająco dobrych” przewodników².

Jak pisze Helena Siwek, nauczyciel

powinien być dobrze przygotowany pod względem: rzeczowym - znać treści nauczania i strukturę tych treści; pedagogicznym i społecznym - organizować proces nauczania zgodnie z celami nauczania oraz z podstawowymi zasadami psychologicznymi i znajomością możliwości swoich uczniów; konstruktywnym - planować

$\overline{1}$ S. Sadecka, Jak być wystarczająco dobrym nauczycielem?, „Uczyć Lepiej” 2013-2014, nr 4, s. 11.

2 N. Boszczyk, O tożsamości zawodowej nauczycieli, https://edunews.pl/badania-i-debaty/opinie/4705-o-tozsamosci-zawodowej-nauczycieli (dostęp: 30.03.2020). 
i stosować w praktyce nauczania dojrzałe zawodowo decyzje, uwzględniające matematyczne, psychologiczne i pedagogiczne czynniki w pełnym zespoleniu, w pełnej integracji ${ }^{3}$.

Tymczasem interdyscyplinarny charakter naszych czasów, stawia nauczycielom większe wymagania niż kiedykolwiek miało to miejsce. Ich rola w stosunku do ucznia ulega redefinicji w kierunku relacji bardziej partnerskich, bardziej trenera, mentora, coacha, lidera i przywódcy edukacyjnej zmiany niż profesora, wykładowcy i egzaminatora. Nie pozostaje to bez wpływu na poczucie tożsamości zawodowej nauczycieli. Istota tych przeobrażeń zawiera się bowiem we wzajemnym oddziaływaniu i współzależności systemu oświatowego i szerszego, w stosunku do niego, systemu społecznego. Bardziej niż specjalisty autonomicznej dziedziny wiedzy, jaką jest matematyka, potrzebujemy osoby biegłej w sprawach uczenia się, która będzie potrafiła odkryć u swoich podopiecznych talent, zapał i entuzjazm. Nauczyciela, który będzie przygotowywał do życia w świecie nieustannej eksploracji i adaptacji. Autorytetu kształtującego charakter, obeznanego z technikami uczenia się akceptującego swoją niedoskonałość, akceptującego fakt, że czasem jest pełen pasji, a czasem pełen rutyny; świadomego swojej wartości, mimo porażek i pomyłek ${ }^{4}$.

Oprócz wysokich kompetencji merytorycznych, prawidłowego posługiwania się pojęciami matematycznymi, umiejętnościami z zakresu dydaktyki matematyki, dobry nauczyciel w opinii uczniów powinien być zafascynowany matematyką. Swoją pasją zarażać innych, poprzez pobudzanie ich do działania i eksperymentowania w obrębie matematyki, do wysuwania hipotez oraz ich weryfikacji. Powinien starać się możliwie najpełniej odpowiedzieć na wyzwania współczesności i potrzeby edukacyjne swoich wychowanków. Jego nadrzędnym celem powinno być kształcenie umiejętności matematycznych koniecznych do funkcjonowania we współczesnym świecie, w szczególności tych umiejętności, które są sensem kształcenia matematycznego, czyli rozumowania i argumentowania. Powinien być przewodnikiem, diagnostykiem i tutorem cieszącym się zaufaniem. Nie tyle zarządcą klasy

3 H. Siwek, Dydaktyka matematyki. Teoria $i$ zastosowania w matematyce szkolnej, WSiP, Warszawa 2005, s. 13.

4 B. Olszak-Krzyżanowska, Poczucie tożsamości zawodowej nauczycieli, „Nauczyciel i Szkoła” 1999, nr 1(6), s. 17-30. 
i dystrybutorem wiedzy, co motywatorem do nauki, organizującym ciekawe sytuacje problemowe prowadzące do odkrywania nowych treści 5 .

Jego zadaniem jest dbanie o to, aby nauka organizowana była w autonomicznych warunkach emocjonalnych ułatwiających prezentowanie własnego stanowiska. Zarazem powinien być on odpowiedzialny społecznie, stanowić wzór do naśladowania poprzez nienaganną postawę etyczno-moralną, kształtującą normy i zasady postępowania. Traktując podmiotowo ucznia i szanując jego prawa pozwalać na popełnianie przez niego błędów jednocześnie będąc otwartym na inne rozwiązania, gotowym, żeby pomóc. Posiadać wiedzę z psychologii rozwojowej i poznawczej człowieka, która pozwoli na wychowanie jednostki „przydatnej” dla społeczeństwa, przyczyniającej się do rozwoju tego społeczeństwa ${ }^{6}$.

W swej pracy powinien być twórczy, otwarty na nowe teorie pedagogiczne, nowe techniki i metody pracy z uczniem. Czuć się zobowiązany do dzielenia się wiedzą i doświadczeniem z innymi nauczycielami - wspierać ich rozwój zawodowy, promując nowe i ulepszone metody nauczania matematyki dbając jednocześnie o osiąganie wysokich standardów. Nie powinien bać się rozpoznawania i rozwiązywania problemów edukacyjnych czy wychowawczych. To indywidualna praca z uczniem, oparta na wzajemnym szacunku wynikającym z godności człowieka, na interakcyjności, czyli współpracy nauczycieli, uczniów, a nawet ich rodziców, przynosi najlepsze efekty wychowawcze? ${ }^{7}$. To przecież zawód, który wymaga odwagi i kreatywności. Znajomości przepisów systemu oświaty, pomocy społecznej lub postępowania w sprawach nieletnich. Umiejętności organizacyjnych - organizowania wycieczek, wyjazdów, akademii, jak i administracyjnych - tworzenie dokumentacji, a obecnie pożądane jest także wykazanie się przedsiębiorczością, w celu pozyskiwania środków i sponsorów zewnętrznych na nagrody dla uczniów oraz dodatkową działalność szkoły ${ }^{8}$.

5 G. Polya, Odkrycie matematyczne, Wydawnictwo Naukowo-Techniczne, Warszawa 1975.

6 M. Czajkowska, M. Orzechowska, Sylwetka dobrego nauczyciela matematyki, [w:] M. Fedorowicz, J. Choińska-Mika, D. Walczak (red.), Liczą się nauczyciele, Instytut Badań Edukacyjnych, Warszawa 2014, s. 198-199.

7 A. Pery, Awans zawodowy nauczyciela - krok po kroku, ORE, Warszawa 2011.

8 M. Czajkowska, M. Orzechowska, Sylwetka dobrego..., s. 198-199. 
Ponadto współczesny nauczyciel musi właściwie wykorzystywać technologie informacyjno-komunikacyjne do wspierania rozwoju myślenia matematycznego uczniów, rozwijając umiejętność wyszukiwania i weryfikowania informacji. Wykorzystując je tylko wtedy, gdy zastosowanie tradycyjnych środków jest np. niemożliwe lub czasochłonne. Robiąc to w sposób dobrze przemyślany i zaplanowany np. do pokonywania blokad emocjonalnych i poznawczych swoich uczniów9.

Przytoczone powyżej wzorcowe umiejętności tj. kompetencje miękkie, społeczne, doświadczenie zawodowe są niezbędne, by polepszyć efekty pracy w szkole. Jednocześnie nie ma takiego drugiego zawodu, który wymagałby równie wielu i tak różnorodnych predyspozycji jak zawód nauczyciela. Pedagodzy i badacze edukacji wskazują jednak, iż wiele z tych zdolności jest bardzo ważnych z punktu widzenia jakości nauczania, mimo iż nie zostały ujęte w przepisach prawa oświatowego ${ }^{10}$. Nauczyciel spośród wielu „dobrych rad” musi sam określić i odnaleźć swoją drogę zawodową, dbając w dużej mierze o to, aby wychowankowie czuli się z nim dobrze, bezpiecznie, widzieli w nim osobę kompetentną do przekazywania wiedzy i wychowania, a rodzice byli usatysfakcjonowani sposobem jego pracy oraz poziomem zdobytej przez ich dzieci wiedzy. Kunszt i mistrzostwo pracy w szkole polega na tym, aby to tworzywo, jakim jest uczeń ukształtować we właściwym kierunku, poprzez pełne poznanie, autentyczne zaangażowanie we współpracę, budowanie relacji i dbałość o drugiego człowieka.

\section{Nauczyciel jako tutour}

Do każdego dziecka, ucznia, studenta czy dorosłej osoby uczącej się trzeba szukać osobnego klucza, by uruchomić jego potencjał. Dlatego też powinno się stosować inne metody pracy, mimo egzystencji w systemach edukacji ukształtowanych na skalę masową. Z pomocą może przyjść tutaj tutoring, który jest specyficzną formą pracy nauczyciela-tutora z uczniem. Nie jest to panaceum na wszystkie problemy

$9 \quad$ Por. P. Remża, Instrumentarium nauczyciela matematyki, [w:] A. Karpińska, M. Zińczuk, P. Remża (red.) Oblicza edukacji w prospektywnym oglądzie, Wydawnictwo Adam Marszałek, Toruń 2019, s. 242-252.

10 K. Hernik, J. Przewłocka, M. Smak, R. Piwowarski, Rozwój kompetencji nauczycieli, [w:] M. Fedorowicz, J. Choińska-Mika, D. Walczak (red.), Liczq się nauczyciele..., s. 130. 
współczesnego szkolnictwa, ale jest jedną ze ścieżek, która prowadzi nas z powrotem do sedna tego, czym jest autentyczna edukacja, gdyż opiera się na relacji człowieka z człowiekiem, tutora z podopiecznym. Jest to podejście zindywidualizowane i całościowe, uwzględniające to, że każdy jest inny i że nasze życie i rozwój odbywają się jednocześnie w wielu sferach. W tutoringu nie tyle chodzi o sprawdzanie, ile ktoś zapamiętał, co o asystowanie w procesie rozwoju - odkrywanie talentów oraz kształcenie umiejętności samodzielnego myślenia i tworzenia.

Tutoring jest formą edukacji spersonalizowanej, szytej na miarę konkretnej osoby, jej talentów i predyspozycji; edukacji, która włącza wszystkie przestrzenie rozwoju osoby, nie tylko wiedzę, ale także umiejętności, postawy i charakter. Metoda ta nie jest przeciwieństwem edukacji masowej. W dzisiejszych uwarunkowaniach może być jej kontynuacją, dopełnieniem. Dzięki naciskowi na samodzielną pracę, na pobudzanie ciekawości i kreatywności tutoring może w efekcie powodować głębsze i bardziej celne korzystanie $\mathrm{z}$ różnych form edukacji masowej, która realizuje się w czasie lekcji. Problemem dzisiejszej edukacji nie jest masowość, lecz to, że została ona praktycznie całkowicie do tego poziomu zredukowana ${ }^{11}$.

To, co wyróżnia tutoring od innych form nauczania, to podkreślanie wagi krytycznego myślenia, twórczego analizowania, klarownego wyrażania idei, sztuki logicznej argumentacji i dyskusji rozwiązania. Toteż kluczowym staje się odnajdywanie własnego głosu definiowanego jako pole wspólne między tym, co robić lubię, w czym jestem dobry i co jest potrzebne. To wszystko ma prowadzić do wykształcenia u podopiecznego umiejętności i nawyku samodzielnego uczenia się i skutecznego radzenia sobie z wyzwaniami i problemami, które będzie napotykał w przyszłości ${ }^{12}$.

Zdecydowana większość nauczycieli spełnia kryteria dobrego tutora. Intuicyjnie stosuje niektóre elementy dialogu z uczniem, aby łatwiej było do niego dotrzeć, potrafi go zrozumieć i doradzić. Zwraca uwagę na jego mocne strony, pomaga je odkryć oraz uświadomić potrzebę ich rozwijania. Im więcej nauczyciel wie o uczniu, tym bardziej może mu pomóc. Pomimo licznych zalet metoda ta nie jest stosowana w polskich szkołach z uwagi na fakt, iż klasy składają się z ponad 20 uczniów. Bliski

11 K. Słaboń, Tutoring: innowacyjna metoda rozwijania kreatywności i samodzielnego myślenia, „Uczyć Lepiej” 2013-2014, nr 4, s. 4-5.

12 K. Słaboń, Tutoring - nowatorska metoda pracy z uczniem zdolnym, https://cw.edu.pl/ strefa/632/ (dostęp: 30.03.2020). 
kontakt z nauczycielem w takich warunkach jest rzeczywiście trudny, a dodatkowa wiedza o uczniu nakłada na prowadzącego zajęcia dodatkowe obciążenia, zmusza do reagowania na zaistniałe sytuacje, ale też często dodatkowo zwiększa poczucie odpowiedzialności za ucznia.

\section{Nauczyciel jako coach}

Nie wszystkie dzieci jednakowo lubią się uczyć naukowo pojmowanej matematyki, nie wszystkie są w stanie i muszą skończyć studia techniczne, ale każdemu z nich powinniśmy pomóc odnieść sukces - na miarę jego możliwości. Tu właśnie z pomocą w nauczaniu - przedmiotu sprawczego niepowodzeń szkolnych, jakim jest matematyka - przychodzi coaching i mentoring, które zupełnie inaczej traktują proces edukacji.

Coaching to niedyrektywna forma pracy z uczniem, polegająca na towarzyszeniu mu w rozwoju, w procesie poznawania samego siebie, odkrywania własnego potencjału oraz wykorzystywania zdobytej wiedzy dla wyznaczania celów, projektowania sposobów ich osiągania oraz skutecznego realizowania. Coaching wymaga umiejętności słuchania i słyszenia tego, co komunikuje uczeń. Praca coacha polega przede wszystkim na zadawaniu i przekazywaniu uczniom wartościowych, eksplorujących, otwierających pytań ${ }^{13}$.

Wykracza to daleko poza ramy tradycyjnego nauczania, albowiem obecnie dla nauczycieli największym wyzwaniem jest to, jak mają motywować uczniów do nauki, a także skutecznie wspierać ich w procesie rozwoju własnego potencjału. Wymaga to od nich przestawienia się: z przekazywania wiedzy na tworzenie przestrzeni do samodzielnego jej konstruowania, szukania odpowiedzi; z oceniania i osądzania na informowanie o postępach; z tendencji do zadawania pytań zamkniętych na zadawanie pytań otwartych, eksplorujących, które skłaniają do myślenia, skonfrontowania się z samym sobą i posiadaną wiedzą; z mówienia na słuchanie, gdzie jedno z podstawowych haseł brzmi: „Pytanie nie jest pytaniem, jeśli znana jest odpowiedż"14.

13 T. Tokarz, Coaching w szkole, „Sygnał. Magazyn Wychowawcy” 2016, nr 4, s. 42.

14 M. Pisarski, Nauczyciel jako coach, [w:] M. Pisarski (red.), Jak wykorzystać metody problemowe w edukacji matematycznej?, Ośrodek Rozwoju Edukacji, Warszawa 2017, s. 4-11. 
Stosując takie podejście sprawiamy, że młodzież szuka odpowiedzi w sobie i nie polega tylko i wyłącznie na mądrzejszych autorytetach. Uczy się rozwiązywania problemów i realizowania własnych celów. Co więcej, wykorzystanie coachingu w edukacji pozwala na uwolnienie się od szkodliwego dla edukacji podejścia - uczymy wszystkich tak samo. Cel jest jeden, uzyskanie maksymalnego potencjału społecznego i intelektualnego człowieka oraz walka z problemami wykluczenia społecznego ${ }^{15}$.

Zadaniem nauczyciela-coacha jest pomoc młodzieży w przejściu z miejsca, w którym się znajduje do miejsca, w którym chce, bądź po prostu musi się znaleźć, poprzez optymalizację działań, trafniejsze decyzje, pełniejsze wykorzystanie zasobów wewnętrznych oraz zewnętrznych. Służy temu wspieranie w poszukiwaniu rozwiązania problemu bez narzucania własnych pomysłów, stwarzanie okazji do wyrażania własnych przekonań i postaw, praca zgodnie z zasadą: mów co chcesz uzyskać, a nie czego nie chcesz mieć, a cele formułuj mówiąc o tym, co można robić lepiej, a nie, co robione jest źle - używaj języka pozytywów. Działania tego typu są uzupełnieniem podstawowych umiejętności pedagogów i mogą dodatkowo stać się początkiem nowego efektywnego nauczania. Edukacji zwiększającej wiedzę, umiejętności i kształtującej osobowość ucznia ${ }^{16}$.

\section{Nauczyciel jako mentor}

Mentoring jest podejściem historycznie i zwyczajowo bardzo mocno zakorzenionym w pedagogice artystycznej. Relacja „mistrz-uczeń” jest jego najwierniejszą realizacją. To jedna z praktycznych metod nauki - równie efektywna jak coaching - bazująca na partnerskiej relacji między mentorem a uczniem. Jej celem jest rozwinięcie potencjału ucznia i przygotowanie go do czekających wyzwań.

Jest terminem stosowanym zazwyczaj do opisania relacji pomiędzy mniej doświadczoną osobą, nazywaną protegowanym lub podopiecznym (...) a osobą bogatszą w doświadczenie, nazywaną mentorem. W tradycyjnym ujęciu mentoring

15 E. Parsloe, Coaching i mentoring, Petit, Warszawa 1998, s. 10.

16 A. Brzeziński, Coaching uczenia się, czyli pomysł na zaangażowanych uczniów, „Dyrektor Szkoły" 2013, nr 9. 
jest postrzegany jako dwuosobowa, bezpośrednia w formie komunikacji i długoterminowa relacja między nadrzędnym mistrzem a wprowadzanym w jakiegoś rodzaju praktykę uczniem ${ }^{17}$.

W definicji podkreśla się, że jest to metoda udzielania rad, wskazówek i informacji przez osobę, która ma doświadczenie, umiejętności lub też wiedzę praktyczną potrzebną do rozwoju zawodowego i osobistego innej osoby. Mentor jednak, pozostając w kontakcie z uczniem, nie jest nastawiony na jego poznawanie, odkrywanie mocnych stron bądź jego talentów. Jest tylko przewodnikiem, doradcą, konsultantem, wspierającym podopiecznego w rozwoju kompetencji zarówno merytorycznych, jak i tych związanych z rozwojem osobistym. Dzieląc się swoją wiedzą i doświadczeniem bazuje na relacji szacunku i zaufania, jest wychowawcą stale pouczającym kogoś, „lubiącym prawić morały”18.

$\mathrm{Z}$ mentoringu korzyści odnoszą także sami mentorzy, rozwijając własne zdolności dydaktyczne, interpersonalne i liderskie, stając się nierzadko autorytetem - mistrzem - obdarzonym szczególną atencją ze strony podopiecznych. $\mathrm{Z}$ powodzeniem może być on wykorzystany do dzielenia się wiedzą i doświadczeniem dobrze wykwalifikowanych nauczycieli z ich młodszymi kolegami i koleżankami wprowadzając do szkoły więcej inspirującego dialogu międzypokoleniowego. Pozwalając łączyć wiedzę i doświadczenie ze świeżym spojrzeniem na matematykę, promującym nowe i ulepszone metody jej nauczania.

Obiektywne spojrzenie na mentoring, pozwala dostrzec zarówno jego zalety, jak też wadę w stosunku do jednostki, a także grup. Relacja mistrz-uczeń może z czasem prowadzić do pewnego rodzaju uzależnienia od drugiej osoby. Jednak wykorzystując zalety i pomijając wadę, można zaryzykować wskazanie, że optimum efektywności uzyskamy łącząc kilka metod. Mentoring jako główny i dostarczający informacji z coachingiem stawiającym pytania i mobilizującym do działania. Mentoring, który jest bardziej naturalny i przydatny w początkowym etapie nauki z coachingiem stosowanym w końcowej fazie nauki, gdy bardziej istotne jest poszukiwanie oryginalności i niepowtarzalności. Nie jest to recepta na sukces, ale jeden z pomysłów umożliwiający

17 B.W. Packard, Definition of Mentoring, American Association for the Advancement of Science 2003, http://ehrweb.aaas.org/sciMentoring/Mentor_Definitions_Packard.pdf (dostęp: 30.03.2020).

18 J. Tokarski (red.), Słownik wyrazów obcych, PWN, Warszawa 1980, s. 467. 
rozwój, choć może się to wiązać z koniecznością zmiany przyzwyczajeń i rutynowego podejścia nauczyciela do ucznia ${ }^{19}$.

\section{Nauczyciel jako trener}

„Trener jest pedagogiem, który opierając się na humanistycznych treściach wychowania, kształcenia i etyki swego zawodu przygotowuje sportowca do życia w społeczeństwie oraz do osiągania sukcesów na miarę jego możliwości" ${ }^{20}$. Podobnie w edukacji, trenerem nazywa się osobę prowadzącą szkolenie lub kurs, którego celem jest nie tyle przekazanie wiedzy, ile trenowanie odpowiednich umiejętności i zachowań ${ }^{21}$. Wynika $z$ tego, iż współczesny trener musi być znakomitym fachowcem, o wszechstronnym wykształceniu ogólnym i specjalistycznym, posiadającym również umiejętności i zdolności do nawiązywania kontaktu, zrozumienia i motywowania pojedynczych osób, jak i całych grup.

Czynności zawodowe trenera to części przedsięwzięć związanych z realizacją procesu dydaktycznego m.in.: opracowanie programu i planu działania, przygotowanie środków niezbędnych do przeprowadzenia procesu nauczania, realizowania zadań wychowawczych, szkoleniowych i organizatorskich jak też i ewaluacja. Jest to proces bardzo złożony oparty na interakcji pomiędzy trenerem i podopiecznym, wywołaniu korzystnych zmian cech osobowych trenowanego, a także przeciwdziałaniu niepożądanym transformacjom. Wynika z tego, że do osiągania wysokich wyników potrzebna jest wzajemna współpraca, a trener jest idealnym nauczycielem. Tym samym „wymagania wobec kwalifikacji zawodowych trenera są rozlegle, gdyż dotyczą rozumienia i posługiwania się w pracy metodami stosowanymi w naukach przyrodniczych, humanistycznych i technicznych"22. Bez tych wszystkich kompetencji trenerskich, nawet dobry nauczyciel matematyki

19 M. Gallas, Relacja mistrz - uczeń: coaching czy mentoring?, „Annales Universitatis Mariae Curie-Skłodowska. Artes" 2018, t. 16, nr 1-2, s. 253-271.

20 Z. Naglak, Metodyka trenowania sportowca, AWF we Wrocławiu, Wrocław 1994, s. 49.

21 A. Postuła, Rozwój podsystemu kulturowego - rozwój i integracja za pomocą metod budowania zespołów, [w:] M. Kostera (red.), Doradztwo organizacyjne. Ujęcie systemowe, Poltext, Warszawa 2013, s. 89-116.

22 Z. Naglak, Społeczne i metodyczne aspekty sportu kwalifikowanego, AWF we Wrocławiu, Wrocław 1987, s. 412. 
pozostanie w szkole bezradny, a stale rozwijająca się wiedza na temat uczenia się, pojawiające się nowe metody i narzędzia dydaktyczne, zmieniają pojmowanie samej edukacji ${ }^{23}$.

Trener w dosłownym tłumaczeniu na język angielski znaczy coach, ale nie oznacza to, że trener równa się coach, mimo iż coaching i trening są często ze sobą powiązane. Trener przede wszystkim przekazuje wiedzę, szkoli, daje wskazówki, rady, podsuwa gotowe rozwiązania i czasem modeluje zachowania. Natomiast rolą coacha jest odkrycie potencjału w człowieku m.in. poprzez zadawanie pytań, pomoc w znalezieniu jego własnych odpowiedzi i rozwiązań, słuchanie, a nie dawanie rad, wydawanie poleceń. Dlatego nazwa zawodu coach nie równa się trener ${ }^{24}$.

Korzystanie z wymienionych tutaj form pracy wymaga pogłębionego wglądu w ich specyfikę, a różnorodność kompetencji między poszczególnymi rolami w procesie nauczania oraz w życiu ucznia została przedstawiona w poniższej tabeli.

Tabela 1. Różnice między nauczycielem, tutorem, coachem, mentorem i trenerem

\begin{tabular}{|c|c|c|c|c|c|}
\hline & 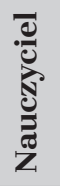 & 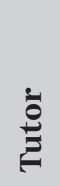 & $\begin{array}{l}\frac{1}{0} \\
0 \\
0\end{array}$ & $\begin{array}{l}\frac{\dot{0}}{\overrightarrow{0}} \\
\frac{\bar{e}}{\sum}\end{array}$ & $\begin{array}{l}\dot{\Phi} \\
\stackrel{\bar{\nu}}{\nu}\end{array}$ \\
\hline Wiedza (przedmiotowa i o uczniu) & $\mathrm{X}$ & $\mathrm{X}$ & & $\mathrm{X}$ & $\mathrm{X}$ \\
\hline Niewiedza (pomoc w osiąganiu celów) & & & $\mathrm{X}$ & & $\mathrm{X}$ \\
\hline Mówienie (przekazywanie wiedzy, inspirowanie) & $\mathrm{X}$ & & & $\mathrm{X}$ & $\mathrm{X}$ \\
\hline $\begin{array}{l}\text { Pytanie (ale nie odpytywanie, } \\
\text { słuchanie odpowiedzi) }\end{array}$ & & $\mathrm{X}$ & $\mathrm{X}$ & & \\
\hline
\end{tabular}

Źródło: opracowanie własne ${ }^{25}$.

23 J. Scheerens, Teachers' professional development: Europe in international comparison: an analysis of teachers' professional development based on the OECD's TALIS, Office for Official Publications of the European Union, Luxembourg 2011.

24 I. Kazimierska, Aspekty praktycznego wykorzystania czynników wpływajacych na motywację wewnętrzną w pracy zespołowej nauczycieli, ORE, Warszawa 2010.

25 Por. A. Sarnat-Ciasto, Tutoring, coaching i mentoring w polskiej szkole? Między chaosem a autentyczna potrzeba, „Podstawy Edukacji. Między Porządkiem a Chaosem” 2015, nr 8, s. 141-152. 
Brak wsparcia pedagogicznego i gotowych rozwiązań w postaci konspektów zajęć z wykorzystaniem technik tutorskich, couchingowych, mentorskich czy trenerskich zniechęcają nauczycieli matematyki do poszukiwania nowych, efektywnych metod pracy.

Jarosław Traczyński, szukając najlepszego rozwiązania dla polskiej szkoły, przyznał, że najlepszym „tutorem jest mentor korzystający z narzędzi coacha"26. Tymczasem jak pokazują badania przeprowadzone w 2013 roku przez Instytut Badań Edukacyjnych, których wyniki opracowane zostały w postaci Raportu o stanie edukacji, nauczyciele uczynili z matematyki pokaz, a z ucznia - biernego widza. Aż 77\% nauczycieli szkoły podstawowej, 88\% nauczycieli gimnazjum, 88\% liceum oraz 97\% nauczycieli technikum i 96\% nauczycieli zasadniczej szkoły zawodowej trenuje rozwiązywanie zadań poprzez prezentację uczniom, krok po kroku, jak należy rozwiązać zadanie matematyczne stosując tę metodę prawie na każdej lekcji, stając się „uczycielami”. Oznacza to prawdopodobnie, że nie potrafią inaczej prowadzić lekcji ${ }^{27}$. Młodzież nie ma szans stać się odkrywcą rozwiązania, a jest jedynie wykonawcą prostych instrukcji. Brak jest tutaj zarówno poszukiwania różnych sposobów rozwiązania danego problemu, jak i dyskusji nad sensownością podawanych przez uczniów propozycji i otrzymanego wyniku. Takie działanie może świadczyć jedynie o braku wiary nauczycieli w możliwości intelektualne uczniów ${ }^{28}$. Można zatem postawić hipotezę, że nauczyciele matematyki doskonale kształcą umiejętności określone w wymaganiach szczegółowych, ale w niewystarczającym stopniu rozwijają umiejętności zapisane w wymaganiach ogólnych podstawy programowej. W systemie szkolnym zadeklarowanych jest wiele ważnych postulatów, choć często są to tylko pobożne życzenia, martwe prawo ${ }^{29}$. Być może nie doceniają znaczenia tych wymagań

26 J. Traczyński, Kim jest (mógłby być...) tutor w polskiej szkole?, [w:] P. Czekierda, M. Budzyński, J. Traczyński, Z. Zalewski, A. Zambrzuska (red.), Tutoring w szkole, między teoriq a praktyka zmiany edukacyjnej, Towarzystwo Edukacji Otwartej, Wrocław 2009, s. 36.

27 M. Czajkowska, M. Orzechowska, Jak pracuja nauczyciele matematyki, [w:] M. Fedorowicz, M. Sitek (red.), Liczą się nauczyciele..., s. 185-196.

28 Ibidem s. 191.

29 Propozycja nowego modelu kształcenia przyszłych nauczycieli, http://kj.edu.pl/ wp-content/uploads/2019/06/Za\%C5\%82\%C4\%85cznik-nr-2a.pdf (dostęp: 30.03.2020). 
w procesie dydaktycznym lub nie wierzą w możliwości swoich uczniów uznając ten sposób prowadzenia lekcji jako wygodny. Klasa może bowiem uzyskać pozytywne oceny z matematyki przy stosunkowo niewielkim wysiłku intelektualnym i nakładzie pracy, stosując algorytmy i wzorcowe rozwiązania zadań prezentowane podczas lekcji.

\section{Czy można wyuczyć się roli nauczyciela?}

Przygotowanie się do zawodu to przede wszystkim konieczność poznania treści programowych i określonego zasobu metod pracy, czyli połączenie tego, czego będziemy uczyć z wiedzą, jak to robić. Nie można jednak pominąć takich składników jak: dojrzały charakter, wysoki poziom moralny, prawość i odwaga. Ale także odpowiedzialność, wytrwałość, umiejętność obserwacji i współpracy, które stanowią ważne cechy profesjonalnego warsztatu. Tym, co tak naprawdę wyróżnia wystarczająco dobrych nauczycieli jest ich postawa. Otwartość na drugiego człowieka i jego potrzeby. Zaufanie, jakim obdarzają swoich uczniów i wiara w możliwości i potencjał swoich podopiecznych. $\mathrm{Na}$ większość tych cech i cnót trzeba sobie samemu zapracować i nie ma ich w ofercie nauczycielskich kursów zawodowych, ale to wcale nie znaczy, że możemy je zlekceważyć, kształcąc nauczycieli ${ }^{30}$.

Praca z uczniem nad matematyką - to nie wszystko. Nie wystarczy nauczyć głównych wzorów, technik i metod rozwiązywania podstawowych zadań z kolejnych działów matematyki. Tak nauczani uczniowie nie poradzą sobie w przyszłości z nietypowymi problemami, a nawet ze stosowaniem typowych metod w nietypowych sytuacjach. Nie rozwiną swojego potencjału intelektualnego i umiejętności rozumowania. Nie będą potrafili powiązać ze sobą pojęć i własności z różnych działów matematyki. Nie wystarczy na lekcjach matematyki uczyć wyłącznie rozumowania, pracować z uczniami głównie nad rozwiązywaniem niestandardowych problemów, skłaniać ich do odkrywania praw i własności matematycznych, gdyż w tym przypadku uczniowie mogą mieć kłopoty z zadaniami, z którymi nie spotykali się na lekcjach, zadaniami wymagającymi biegłego opanowania typowych procedur. Oba

30 G. Czetwertyńska, Stać się nauczycielem, [w:] W. Bobiński, J. Sujecka-Zając (red.), Kształcenie nauczycieli - wyzwanie i zaangażowanie, Wydawnictwo Universitas, Kraków 2019, s. 55-66. 
podejścia, instrumentalne i relacyjne, są potrzebne do harmonijnego rozwoju matematycznego - one się uzupełniają, a nie wykluczają ${ }^{31}$.

Człowiek jest istotą społeczną - wiedza o sobie i innych, rozumienie siebie i umiejętność organizacji własnej pracy przyczyniają się do czerpania satysfakcji z życia. Szkoła, klasa, a przede wszystkim nauczyciel odgrywają kluczową rolę w kształtowaniu kompetencji miękkich. Dzieje się to często na bazie dobrej, bezpiecznej, głębokiej relacji z uczniem, niezależnie czy jest to relacja trenerska, mistrzowska, coachingowa czy tutorska.

\begin{abstract}
The aim of the article is to analyze and present the teacher's roles in moThe aim of the article is to analyse and present the teacher's roles in modern school, in comparison to the tutor, coach, mentor, and trainer. The article shows the need to change the meaning of the role of a specialist teacher in a given subject, to a mentor using the tools of a coach or a tutor supporting the development of the mentee. The author introduces the social competences of a modern mathematics teacher and provides in-depth insights into their specificity. It raises the need to change the way of teaching in order to improve the effects of work at school, but also draws attention to succumbing to fashion for a given method and applying its innovativeness without a deeper insight into the legitimacy of its implementation.
\end{abstract}

\title{
Bibliografia
}

Brzeziński A., Coaching uczenia się, czyli pomysł na zaangażowanych uczniów, „Dyrektor Szkoły” 2013, nr 9.

Czajkowska M., Orzechowska M., Jak pracują nauczyciele matematyki, [w:] M. Fedorowicz, M. Sitek (red.), Liczą się nauczyciele, Instytut Badań Edukacyjnych, Warszawa 2014.

Czajkowska M., Orzechowska M., Sylwetka dobrego nauczyciela matematyki, [w:] M. Fedorowicz, J. Choińska-Mika, D. Walczak (red.), Liczą się nauczyciele, Instytut Badań Edukacyjnych, Warszawa 2014.

Czetwertyńska G., Stać się nauczycielem, [w:] W. Bobiński, J. Sujecka-Zając (red.), Kształcenie nauczycieli - wyzwanie i zaangażowanie, Wydawnictwo Universitas, Kraków 2019.

Gallas M., Relacja mistrz - uczeń: coaching czy mentoring?, „Annales Universitatis Mariae Curie-Skłodowska" 2018, t. 16, nr 1-2.

31 M. Karpiński, Czy każdego można nauczyć matematyki? [w:] W. Bobiński, J. Sujecka-Zając (red.), Kształcenie nauczycieli..., s. 160. 
Hernik K., Przewłocka J., Smak M., Piwowarski R., Rozwój kompetencji nauczycieli, [w:] M. Fedorowicz, J. Choińska-Mika, D. Walczak (red.), Liczą się nauczyciele, Instytut Badań Edukacyjnych, Warszawa 2014.

Karpiński M., Czy każdego można nauczyć matematyki? [w:] W. Bobiński, J. Sujecka-Zając (red.), Kształcenie nauczycieli-wyzwanie i zaangażowanie, Wydawnictwo Universitas, Kraków 2019.

Kazimierska I., Aspekty praktycznego wykorzystania czynników wpływających na motywację wewnętrzną w pracy zespołowej nauczycieli, ORE, Warszawa 2010.

Naglak Z., Metodyka trenowania sportowca, AWF we Wrocławiu, Wrocław 1994.

Naglak Z., Społeczne i metodyczne aspekty sportu kwalifikowanego, AWF we Wrocławiu, Wrocław 1987.

Olszak-Krzyżanowska B., Poczucie tożsamości zawodowej nauczycieli, „Nauczyciel i Szkoła” 1999, nr 1(6).

Parsloe E., Coaching i mentoring, Petit, Warszawa 1998.

Pery A., Awans zawodowy nauczyciela - krok po kroku, ORE, Warszawa 2011.

Pisarski M., Nauczyciel jako coach, [w:] M. Pisarski (red.), Jak wykorzystać metody problemowe w edukacji matematycznej?, Ośrodek Rozwoju Edukacji, Warszawa 2017.

Polya G., Odkrycie matematyczne, Wydawnictwo Naukowo-Techniczne, Warszawa 1975.

Postuła A., Rozwój podsystemu kulturowego - rozwój i integracja za pomocą metod budowania zespołów, [w:] M. Kostera (red.), Doradztwo organizacyjne. Ujęcie systemowe, Poltext, Warszawa 2013.

Remża P., Instrumentarium nauczyciela matematyki, [w:] A. Karpińska, M. Zińczuk, P. Remża (red.) Oblicza edukacji w prospektywnym ogladzie, Wydawnictwo Adam Marszałek, Toruń 2019.

Sadecka S., Jak być wystarczająco dobrym nauczycielem?, „Uczyć Lepiej” 2013-2014, nr 4.

Sarnat-Ciasto A., Tutoring, coaching i mentoring w polskiej szkole? Między chaosem a autentyczną potrzebą, „Podstawy Edukacji. Między Porządkiem a Chaosem" 2015, nr 8.

Scheerens J., Teachers' professional development: Europe in international comparison: an analysis of teachers' professional development based on the OECD's TALIS, Office for Official Publications of the European Union, Luxembourg 2011.

Siwek H., Dydaktyka matematyki. Teoria $i$ zastosowania w matematyce szkolnej, WSiP, Warszawa 2005. 
Słaboń K., Tutoring: innowacyjna metoda rozwijania kreatywności i samodzielnego myślenia, „Uczyć Lepiej” 2013-2014, nr 4.

Tokarski J. (red.), Słownik wyrazów obcych, PWN, Warszawa 1980.

Tokarz T., Coaching w szkole, „Sygnał. Magazyn Wychowawcy” 2016, nr 4.

Traczyński J., Kim jest (mógtby być...) tutor w polskiej szkole?, [w:] P. Czekierda, M. Budzyński, J. Traczyński, Z. Zalewski, A. Zambrzuska (red.), Tutoring w szkole, między teoriq a praktyka zmiany edukacyjnej, Towarzystwo Edukacji Otwartej, Wrocław 2009.

\section{Netografia}

Boszczyk N., O tożsamości zawodowej nauczycieli, https://edunews.pl/ badania-i-debaty/opinie/4705-o-tozsamosci-zawodowej-nauczycieli (dostęp: 30.03.2020).

Packard B.W., Definition of Mentoring, American Association for the Advancement of Science 2003, http://ehrweb.aaas.org/sciMentoring/Mentor_Definitions_Packard.pdf (dostęp: 30.03.2020).

Propozycja nowego modelu kształcenia przyszłych nauczycieli, http:// kj.edu.pl/wp-content/uploads/2019/06/Za\%C5\%82\%C4\%85cznik-nr-2a.pdf (dostęp: 30.03.2020).

Słaboń K., Tutoring - nowatorska metoda pracy z uczniem zdolnym, https://cw.edu.pl/strefa/632/ (dostęp: 30.03.2020). 